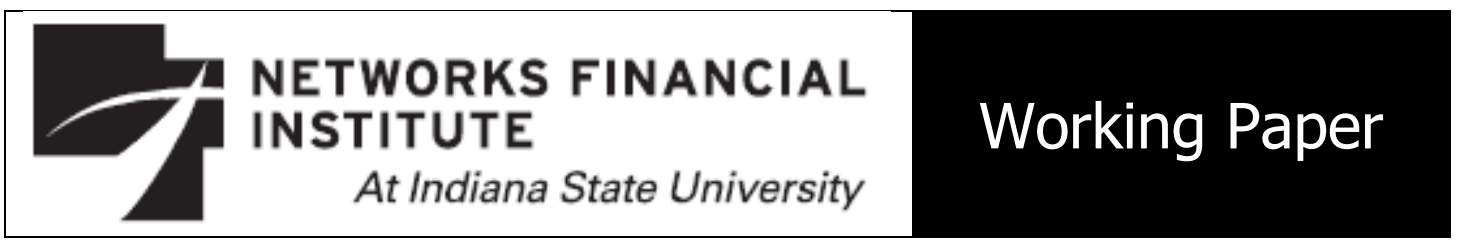

2013-WP-02

December 2013

\title{
Globalization and Inflation: A Swiss Perspective
}

\author{
John A. Tatom
}

Abstract: Globalization has given rise to new concerns that domestic inflation is caused by global developments, especially in the state of the global gap in GDP and resource utilization, and whether domestic monetary policy can control it. This paper explores the role of globalization, if any, for inflation, particularly in Switzerland, one of the smallest and most open economies where the globalization hypothesis should be most relevant, but where inflation historically has been among the lowest in the world. Is Switzerland and Swiss monetary policy unique in providing a benchmark for price stability, or is Swiss inflation performance an accident, with Swiss inflation being dictated by global experience or at least by its larger neighbors? It provides tests of whether inflation in Switzerland is causally related to inflation elsewhere. It focuses in more detail on Swiss inflation in a P* model and on whether it is also influenced by inflation in Germany, other countries or by inflation abroad via an import channel. Finally, the paper looks more broadly at other evidence of whether Swiss inflation or that in other industrial countries is influenced by globalization. Swiss inflation is largely made at home. There is evidence presented of a cointegrating relationship of Swiss and German inflation, but this and the high correlation of Swiss and German inflation are more likely due to common inflation objectives.

About the Author: John A. Tatom is Research Scholar and former Director of Research at Networks Financial Institute, Scott College of Business, Indiana State University and Fellow, Institute of Applied Economics, Global Health and the Study of Business Enterprise, the Johns Hopkins University. He has published widely on international and domestic monetary and fiscal policy issues, the macroeconomics of supply, especially oil and energy price shocks, exchange rates, and on financial innovations.

Keywords: Inflation, Globalization, Switzerland, GDP gap

JEL classification: E31, E32, F4, F8

This paper was largely completed while the author was a Visiting Scholar at the Swiss National Bank. I am indebted to Katrin Assenmacher, Mathias Zurlinden and Samuel Reynard for comments and advice. Any errors or omissions are the responsibility of the author. The views expressed are those of the individual author and do not necessarily reflect official positions of Networks Financial Institute. Please address questions regarding content to John A. Tatom at jtatom@earthlink.net.

NFI working papers and other publications are available on NFI's website (www.networksfinancialinstitute.org). Click "Research" and then "Publications/Papers." 


\section{Globalization and Inflation: A Swiss Perspective}

\section{John A. Tatom}

The Great (and Global) Moderation in inflation since the mid-1980s has given rise to two distinct paths of inflation analysis. The first is that inflation is globally determined and that global inflation has slowed and appears to be more uniformly benign. Thus one might conclude that Swiss policymakers do not need to concern themselves with inflation and perhaps their own efforts to alter inflation would be doomed to failure. Ciccarelli and Mojon (2010) argue that inflation in industrial countries is largely global and the individual country inflation rates converge to this global pace. Major theoretical advances especially by Woodford (2008) suggest that national central banks have little control over inflation because it is global and, more importantly, not amenable to control by domestic monetary policy. Meanwhile, Gattini and Schuhknecht (2012) find that global money determines global inflation, along with indirect transitory influences such as commodity prices and house prices.

Inflation for over a quarter century has taken on a more global pattern that is beyond the control of any one nation, according to some analysts. Applied to Switzerland, all countries' inflation rates are rooted in a global inflation process and domestic influences are secondary at best. The case is strongest, presumably in small open economies and Switzerland provides the best case of the latter and should provide the strongest evidence of the global inflation hypothesis. In particular, the advent of the euro and the growth of the euro-area resulted in most major Swiss trading partners using the same currency and so competition for individual goods and services across borders would have put Swiss prices beyond the control of the Swiss National Bank (SNB) under the globalization hypothesis.

The second analytical path fostered by globalization and the global slowing in inflation is to adapt a more Keynesian approach that focuses on excess domestic demand as the determinant of domestic inflation. In this view, the extent of domestic unemployment of labor and other resources determines the presence of cost and price pressures in the economy, either on top of globally determined inflation or that completely determined by the state of excess demand globally. In this approach, global excess demand for goods and services, measured by the gap in actual real GDP over potential GDP, is the principal determinant of inflation and a large negative gap restrains global price pressures and inflation. See Borio and Filardo (2007) for a focus on the global GDP gap as the determinant of inflation. Others have argued that the domestic gap is critical to the pace of inflation in particular economies, as a domestic component of the global inflation process or as the sole determinant of domestic inflation. See Morley, Piger and Rasche (2012) for evidence on the significant role of country specific gaps, measured by the excess of the unemployment rate over a country specific natural unemployment rate, in determining the transitory component of G-7 countries' inflation rates 
over a global trend. However, Piger and Rasche (2008) find that in the United States the dominant factor accounting for inflation is a time varying long-term trend and that it dominates the role of the GDP gap, which accounts for less than 10 percent of personal consumption and GDP price deflators, but up to 30 percent of Consumer Price Index (CPI) inflation over some short samples. They do not test whether this time varying trend is related to the low frequency trend in money growth.

Neely and Rapach (2011) distinguish global, regional and domestic components of inflation and find that about half ( 49 percent) of domestic inflation is due to national factors and that the rest is determined externally, much less than suggested by Ciccarelli and Mojon (2010) or Borio and Filardo (2007). However, Woodford (2009) argues that globalization has not lessened the ability of domestic central banks to control domestic inflation. More traditional results are found by Sanchez-Fung (2012) who examines three monetary aggregate measures and two interest-rate spreads for inflation in China and finds that only $\mathrm{M} 1$ is systematically related to inflation. His results are at odds with earlier results for the United States of Bernanke and Blinder (1988, 1992) and by Estrella and Mishkin (1997). They are, however, consistent with more recent findings by Leeper and Roush (2003) and by Belongia and Ireland (2012). McCallum and Nelson (2011) provide broad support for the role of money in determining inflation in industrial countries. The European Central Bank continues to focus more extensively on monetary aggregates in the conduct of their monetary policy strategy, despite a downgrading of its role as a central pillar of policy. Hall, Swamy and Tavlas (2012) find that uncertainty plays a central role in money demand and that uncertainty is mean-reverting, if not stationary, providing a basis for a reevaluation of the continuing role of $\mathrm{M} 3$ as a pillar for inflation policy in the Euro-area.

These studies frame the issues quite well. Globalization provides a newer venue for arguments about domestic inflation determinants and control. A focus on global money or a global gap is a natural consideration, given the earlier evolution of debates about the determinants and control of inflation, as are a focus on domestic gaps, financial factors or perhaps even domestic monetary measures or central bank activity to control money.

In this paper, we examine the role of globalization, if any, for Swiss inflation. Is Switzerland and Swiss monetary policy unique in providing a benchmark for price stability, or is Swiss inflation performance an accident, with Swiss inflation being dictated by global experience or at least by its larger neighbors? One of the oldest principles of economics is that the general level of domestic prices is determined by domestic money. Increases (decreases) in inflation are preceded by increases (decreases) in money growth. Recently this relationship has been confirmed for Switzerland by Baeriswyl et al (2013) and, for the United States, Euro-area and Switzerland, by Reynard (2007). But the globalization hypothesis is that this is no longer the 
case or at least that inflation is heavily influenced or completely determined by the degree of global resource utilization, the global GDP gap.

In the first section we review over 50 years of Swiss inflation experience relative to the rest of the world. In section II, we test whether Swiss inflation is statistically and significantly related to inflation abroad, especially to one or more of its neighbors. In section III, we focus in more detail on whether Swiss inflation is influenced by inflation policies in Germany, and via its heir to its focus on price stability, the European Central Bank. Earlier evidence, Kool and Tatom (1994), find that the price level in Switzerland and in several other small open economies is influenced by the adjustment to German prices. Using the $\mathrm{P}^{*}$ model for Switzerland, the tests here reexamine whether the domestic and flexible exchange rate $\mathrm{P}^{*}$ model is supported by the and whether German prices or other foreign prices influence Swiss prices in that context. data Section IV looks more broadly at other evidence of whether Swiss inflation or that in other industrial countries is influenced by globalization. Section $\mathrm{V}$ provides a summary of conclusions and the implications for monetary policy.

\section{Swiss Inflation in a Disinflationary Environment}

Swiss inflation has remained low in recent years, following a long-standing pattern. However, inflation in most other countries has declined sharply since the Great Inflation in the United States (1965-1984) and elsewhere, see Meltzer (2005) for an analysis of the Great Inflation in the United States, though the phenomenon and explanations are nearly the same in most countries that experienced it. Chart 1 shows the year-over-year Swiss inflation rate since 1958, along with an average for 19 countries and the International Monetary Fund (IMF) world inflation measure that begins in 1969. The 19 countries include the biggest European Union members who use the euro since 1999, the United States, Canada, Japan, as well as Switzerland, Denmark, Sweden and the United Kingdom. The global and 19-country measures of inflation suggest that the Great Inflation continued somewhat longer outside the United States. The Great Inflation continued into the mid-1990s for most of the world, according to the IMF measure.

Switzerland, except for the early period 1969-73, 1978-79, and 1985-1990, avoided the Great Inflation. During those episodes, the Swiss National Bank faced strong appreciation of the currency and resisted the real effects of appreciation by more rapid monetary growth and inflation. Swiss inflation has been negative during some periods since 2009 , though this is not too unusual for Switzerland. There have been spikes in inflation, usually related to global energy price spikes, but also during other periods such as the late-1960s and early 1970s. Energy price shocks are most apparent in the 1973-75, the early 1980s, early 1990s and in 2008. Similar spikes occur in the broader groupings showing the global common shocks. 
The three periods noted above, 1969-73, 1978-79 and 1985-90, were all characterized by Swiss concern for an appreciating currency and resistance to its supposed adverse real effects reducing exports, output and employment. Mishkin (2007, p. 642-643) discusses the global impetus to inflation emanating from the United States, which put pressure on the fixed exchange rate system and monetary growth and inflation in Switzerland. He also points to the failure of monetary targeting in the 1978-80 episode when again appreciation pressures led Swiss monetary policy to adopt what Baltensperger (2007) and others refer to as a temporary exchange rate target. Neumann (2007, pp. 736-742) describes the situation similarly, but does not go so far as to refer to a "temporary exchange rate target." As all three authors indicate, the source of the Swiss policy problem was an acceleration in U.S. monetary growth and inflation, with consequent appreciation pressures on the Swiss franc and other currencies. The latter view of course shows that it was not a failure of monetary targeting per se, but rather its abandonment temporarily in favor of an exchange rate target. Finally, the third case again was the result of CHF currency appreciation, emanating again from rapid monetary expansion in the United States and what Baltensperger (2007) refers to as "unintended monetary expansion" in Switzerland.

\section{Chart 1}

Inflation has slowed in most countries

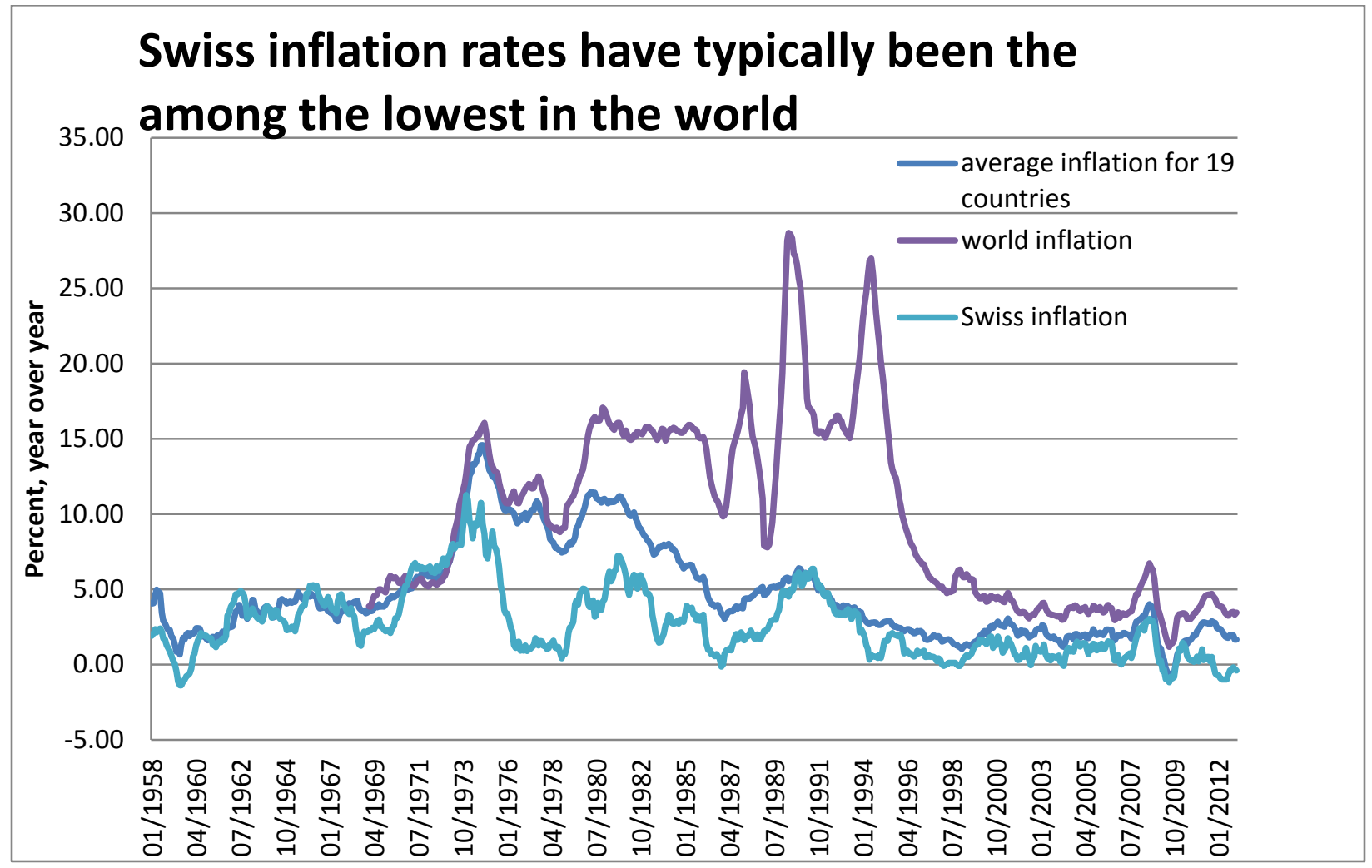


The IMF measure of world inflation remains relatively high until the mid-1990s, but it declines to the 5 percent range or less for the next two decades. It includes many countries that had very high inflation during the Great Inflation period and subsequently. The 19-country measure includes advanced industrial countries with generally more independent central banks that more easily took advantage of the opportunities to reduce inflation after the mid- to late1980s.

The impetus to reduce global inflation is most well known in the Euro-area, where EU efforts began in the early 1990s to move toward a common currency, in part due to the high inflation and exchange rate instability that characterized the Great Inflation period in Europe. Meltzer (2005) explains that the Great Inflation in the United States began due "to analytical errors, particularly the widespread acceptance of the simple Keynesian model with its implication that monetary and fiscal policy should be coordinated" (p.145). And it continued because of "political choices, analytical errors, and the entrenched belief that inflation would continue" ( $p$. 145). The same forces were even stronger and persisted longer in the rest of the world.

Table 1 focuses on Swiss inflation compared with the countries used here that formed the Euro-area, the United States and Japan for the 14-year period since the introduction of the euro, the previous 14 years, roughly corresponding to the end of the Great Inflation, and the 27 years before that. Switzerland had the lowest inflation rate of all the countries shown since 1957, averaging 2.6 percent per year on a year-over-year basis. For the full period, Germany (West Germany only before 1992) averaged 2.7 percent, Japan 3.1 percent, the United States 3.8 percent, and the Euro-area countries 5.1 percent. When the periods are broken down, the decline in mean inflation in each period is more clear and universal.

Note in Table 1 that the Euro-area had the largest decline over the past 14 years (1.88 percent), but it had a larger decline in the 14 years before the introduction of the euro ( 2.78 percent). Two measures of inflation variability are shown in the table; the standard deviation of the inflation rate (S.D.) and the coefficient of variation (C.V.), which is the standard deviation divided by the mean. The latter adjusts for the fact that usually the standard deviation declines (rises) when inflation declines (rises). The standard deviation declines over the three periods along with the inflation rate, except during the past 14 years in the United States when the standard deviation rose slightly $(0.15)$ percent, while inflation fell by 0.77 percentage points.

The coefficient of variation does not show such a clear pattern of decline, however. Most notably, the Euro countries' inflation had a nearly unchanged coefficient of variation in the 14 years since the euro began ( 0.41 percent) compared with the previous 14 years ( 0.39 percent). Switzerland and the United States had a rise in the coefficient of variation during the euro period compared with the previous 14 years and Japan had a larger decline in the mean 
inflation rate than decline in the standard deviation of inflation, but the coefficient of variation was negative, reflecting the slight mean deflation over the period.

Table 1

Declining Inflation in the Euro-area and Elsewhere (Percent)

\begin{tabular}{|c|c|c|c|c|}
\hline & Switzerland & $\begin{array}{c}\text { Euro-area } \\
(15) \\
\end{array}$ & US & Japan \\
\hline \multicolumn{5}{|c|}{ 1958-2012 } \\
\hline Mean & 2.63 & 5.05 & 3.82 & 3.12 \\
\hline S.D. & 2.32 & 3.41 & 2.70 & 4.04 \\
\hline C.V. & 0.88 & 0.68 & 0.71 & 1.30 \\
\hline \multicolumn{5}{|c|}{ 1958-1984 } \\
\hline Mean & 3.75 & 6.89 & 4.79 & 5.70 \\
\hline S.D. & 2.37 & 3.71 & 3.30 & 4.13 \\
\hline C.V. & 0.63 & 0.54 & 0.69 & 0.72 \\
\hline \multicolumn{5}{|c|}{ 1985-1998 } \\
\hline Mean & 2.25 & 4.11 & 3.22 & 1.23 \\
\hline S.D. & 1.80 & 1.60 & 1.12 & 1.17 \\
\hline C.V. & 0.80 & 0.39 & 0.35 & 0.95 \\
\hline \multicolumn{5}{|c|}{ 1999-2012 (Euro) } \\
\hline Mean & 0.75 & 2.23 & 2.45 & -0.28 \\
\hline S.D. & 0.85 & 0.91 & 1.26 & 0.75 \\
\hline C.V. & 1.13 & 0.41 & 0.52 & -2.64 \\
\hline \multicolumn{5}{|c|}{$\begin{array}{l}\text { Percentage-point } \\
\text { decline: }\end{array}$} \\
\hline \multicolumn{5}{|c|}{$1985-98$} \\
\hline Mean & 1.50 & 2.78 & 1.57 & 4.47 \\
\hline S.D. & 0.57 & 2.12 & 2.18 & 2.96 \\
\hline \multicolumn{5}{|c|}{ 1999-2012 } \\
\hline Mean & 1.50 & 1.88 & 0.77 & 1.51 \\
\hline S.D. & 0.94 & 0.69 & -0.15 & 0.42 \\
\hline
\end{tabular}

Chart 1 and Table 1 show that inflation has declined over the past half century, and relatively more outside of Switzerland. This decline and the appearance of convergence elsewhere suggest to many that the inflation process has changed globally. Perhaps Switzerland is "the exception that proves the rule," but there does not appear to be convergence for Switzerland, or perhaps for Japan after the late 1980s. Instead inflation has continued to trend lower. Nonetheless, it is important to review more systematically whether inflation developments in Switzerland are tied to external forces. 


\section{Is Swiss Inflation Tied to Foreign Inflation?}

In this section we examine whether inflation in Switzerland is tied to inflation in the other 18 countries included in the broad country average shown in Chart 1. To do this we take the CPI data from the IMF data base (see International Monetary Statistics, various issues) and perform causality tests for bilateral pairs of inflation (first-differences of the natural logarithm of the CPI). Generally the annual inflation rates are available for 1958 to 2012, except in Denmark where prices begin in 1967 and in Ireland where prices begin in 1997. The results are shown in Table 2.

\section{Table 2}

\section{Granger Causality Test for Swiss Inflation and Inflation in Seven Countries} 1958-2012

\section{( 2 lags of both measures)}

German inflation does not cause inflation in Switzerland

Swiss inflation does not cause inflation in Germany

French inflation does not cause inflation in Switzerland

Swiss inflation does not cause inflation in France

Italian inflation does not cause inflation in Switzerland

Swiss inflation does not cause inflation in Italy

Austrian inflation does not cause inflation in Switzerland

Swiss inflation does not cause inflation in Austria

Belgian inflation does not cause inflation in Switzerland

Swiss inflation does not cause inflation in Belgium

Dutch inflation does not cause inflation in Switzerland

Swiss inflation does not cause inflation in the Netherlands

Portuguese inflation does not cause inflation in Switzerland

Swiss inflation does not cause inflation in Portugal

Irish inflation does not cause inflation in Switzerland

Swiss inflation does not cause inflation in Ireland

Finnish inflation does not cause inflation in Switzerland

Swiss inflation does not cause inflation in Finland

Greek inflation does not cause inflation in Switzerland

$\begin{array}{cc}\text { F-statistic } & \text { Probability } \\ 1.29 & 0.29 \\ 0.64 & 0.53\end{array}$

$0.88 \quad 0.42$

$0.20 \quad 0.81$

$0.06 \quad 0.94$

$0.94 \quad 0.40$

$1.21 \quad 0.31$

$4.60 \quad 0.01 *$

$1.23 \quad 0.30$

$5.15 \quad 0.01 *$

$0.28 \quad 0.76$

$3.37 \quad 0.04 *$

$0.07 \quad 0.94$

$0.07 \quad 0.93$

$1.01 \quad 0.41$

$1.98 \quad 0.20$

$0.15 \quad 0.86$

$1.77 \quad 0.18$

$3.94 \quad 0.03 *$ 
Swiss inflation does not cause inflation in Greece

Spanish inflation does not cause inflation in Switzerland

Swiss inflation does not cause inflation in Spain

Luxembourg inflation does not cause inflation in Switzerland

Swiss inflation does not cause inflation in Luxembourg

U.S. inflation does not cause inflation in Switzerland

Swiss inflation does not cause inflation in the U.S.

Japanese inflation does not cause inflation in Switzerland

Swiss inflation does not cause inflation in Japan

Danish inflation does not cause inflation in Switzerland

Swiss inflation does not cause inflation in Denmark

U.K. inflation does not cause inflation in Switzerland

Swiss inflation does not cause inflation in the U.K.

Canadian inflation does not cause inflation in Switzerland

Swiss inflation does not cause inflation in Canada

Swedish inflation does not cause inflation in Switzerland

Swiss inflation does not cause inflation in Sweden
0.71

3.51

$0.04 *$

0.89

4.14

0.42

4.14

0.15

1.77

0.86

1.77

1.73

1.42

0.19

1.42

1.03

0.07

0.37

1.05

1.05
1.99

0.36

1.99

0.14

0.08

0.87

0.58

0.58

0.27

0.56

0.76

In each case, two lags of a foreign inflation rate were added to an autoregressive model of inflation (also with two lags) to determine whether foreign inflation adds in a statistically significant way to the autoregressive model of domestic inflation. There is only one case where inflation abroad significantly affects inflation in Switzerland: Greece! The correlation of one lag of Greek inflation and Swiss inflation is 0.33 and does not appear to be due to one or two observations. However, when only one lag is used for each inflation rate, the F-statistic for the hypothesis that Greek inflation causes Swiss inflation falls to 0.09 and the probability level is 0.76, strongly rejecting the hypothesis that Greek inflation causes Swiss inflation. It remains the case that one cannot reject the hypothesis that Swiss inflation does not cause Greek inflation (F-statistic 1.72, probability 0.20 ). In no other case can one reject the hypothesis that inflation abroad does not cause Swiss inflation. In an autoregressive model of Swiss inflation only one lag is statistically significant.

The reverse causality tests are somewhat more interesting. In five countries, one can reject the hypothesis that Swiss inflation does not cause inflation there: Austria, Belgium, Luxembourg, 
the Netherlands and Spain. Except for the latter, all are small open economies that were, like Switzerland, tied through common commitments to inflation stability with Germany, see Tatom (1994). Except for the Greek results above, similar results as shown in the table are obtained with only one lag of inflation in each country (not reported). In the tests with only one lag, two more countries can be added to the list where Swiss inflation causes foreign inflation: the U.K. and Finland, bringing to seven, nearly half, the number of countries.

A similar test can be conducted for the variant of the imported inflation hypothesis. Do Swiss import prices affect Swiss inflation? To test this hypothesis, the price deflator for Swiss imports of goods and services from the System of National Accounts from 1957 to 2012 is used. Two lags of the rate of increase of Swiss imports and of the CPI are examined for Granger causality. Import prices do not affect inflation, nor does Swiss inflation affect the rate of increase in imports prices. The F-statistic with two lags for whether Swiss import price increases affect Swiss inflation is 0.18 (probability equals 0.84 ) and for reverse causality, it is 2.29 (probability equals 0.11 ), neither is statistically significant at a 5 percent significance level. With one lag the probability for Swiss import prices to have a statistically significant effect on Swiss inflation is 0.20 and for reverse causality it is 0.47 , far above the five percent criteria used here. With the questionable exception of Greece, inflation abroad does not Granger-cause inflation in Switzerland, including foreign price increases that are transmitted through the prices of Swiss imports.

III. Are Swiss Prices and Inflation Tied to German/European Central Bank Policies?

There is some evidence that Swiss prices and inflation are tied to German prices and inflation, despite the finding above that rejects Granger causality in either direction between German and Swiss inflation. Kool and Tatom (1994) find that that there is a German equilibrium price level (P-Star) toward which five small open European countries also gravitate to a degree dependent upon the relative fixity of their exchange rate and their sharing of a common commitment to price stability. In the Swiss case, the link is the weakest, but the gap between Swiss prices and the Swiss price of German goods and services remains a significant determinant of Swiss price movements. After all that Germany has experienced since then, it is useful to see whether there are remnants of this relationship. Following German reunification and, more important, the introduction of the euro in 1999, it cannot be said that Germany and the Bundesbank determine the German price level independently. This task is left, if to any institution, to the European Central Bank, which has deep roots in the German Bundesbank commitment to price stability. Besides posing a question of significant general interest to policymakers and the public, the question has taken on even greater importance in light of the strong appreciation of the Swiss franc. The potential influence of German and other euro-area 
prices through the exchange rate poses a key question for the Swiss. Does Swiss franc appreciation hold down inflation?

Tatom (1996) asks the broader question of whether Swiss franc appreciation had destructive effects for the economy. The answer is strongly to the contrary. Currency appreciation, in the 1990 s at least, reflected policies that made the economy strong, an unusually strong commitment to price stability and to a role of government in the economy via relatively low taxes and essential public spending that boosted private investment incentives, productivity growth and faster overall economic growth. In the earlier case in the 1990s, Swiss economic performance was held back by a sharp decline in the growth rate of the labor force, lowering the growth rate of productive capacity or potential output growth and supporting the appearance of stagnation. In the latest case, strong appreciation has been associated not only with a continued and credible monetary policy committed to price stability, but also by an acceleration in labor force growth that reinforces the gains in potential output. But uncertainty over the global influences of a weak economic expansion and the potential to return to an economic crisis, primarily in Europe, threatens Swiss possibilities. Moreover, there is a large overhang of Swiss money supply that risks a breakout of inflation from the deflationary bonanza of the past three years. Also there is a risk that the recent appreciation of the Swiss franc relative to the euro will serve as an independent force pushing down Swiss prices or that the policy actions taken to resist appreciation could lead to an outbreak of future inflation.

\section{IIIa. Another Prior Swiss Appreciation Episode: Is a Surge in Inflation Likely?}

In earlier times the Swiss franc was often assessed on the basis of its movements relative to the currency of its largest neighbor and trading partner, Germany. Since reunification in the early 1990s, German prices have been measured on a broader unified German basis and prices earlier must be chained to those in order to determine CPI experience. Moreover, the introduction of the euro in 1999 means that former movements in the Deutschemark can only be linked for Germany to the subsequent movement since the euro. This is done here by linking the pre-1999 DEM exchange rate with the Swiss franc at the prevailing conversion rate of DEM per euro of $1.95583 \mathrm{DEM}$ /euro on January 1,1999 . The resulting nominal exchange rate in euro per Swiss franc is shown in Chart 2 since 1957, along with the real exchange rate for Germany vis $a$ vis the Swiss franc by adjusting for the relative price of goods and services in Switzerland relative to Germany. The relative price level and real exchange rate are also shown in Chart 2.

The Swiss franc appreciated in real (nominal) terms about 42.8 (48.0) percent against the euro from July 2007 to August 2011, using the CPI in Switzerland and Germany to measure the real exchange rate. Over the next 18 months (to February 2013), the real (nominal) exchange rate fell about 11.8 (8.9) percent, but the nominal and real exchange rates declined largely under 
pressure and intervention by the Swiss National Bank's action to put a floor under the euro (a ceiling on the Swiss franc) in August 2011. The question is what comes next? To put the latest appreciation in perspective, it was the largest appreciation against Germany, Switzerland's largest trading partner, then and now) since the mid-1970s, when the real (nominal) exchange rate against Germany rose some 55.9 (50.8) percent from September 1973 to September 1978, a longer period (60 months vs. 49 months), but a slightly slower pace of appreciation. The real exchange rose at a 9.1 percent annual rate in the latest period, faster than the 8.6 percent rate in the mid-1970s. Similarly, the nominal exchange rate rose at a 10 percent annual rate during the recent appreciation, faster than the 9.3 percent rate in the mid-1970s. The earlier appreciation of the Swiss franc followed the end of Bretton Woods, which had probably left the Swiss Franc largely undervalued, but the appreciation shown here is relative to the Deutsche Mark, the forerunner of the euro, and a currency that was also likely to have been undervalued relative to the U.S. dollar.

\section{Chart 2}

Prices in Germany and Switzerland move in a narrow band, as do the nominal and real exchange rate-until recently

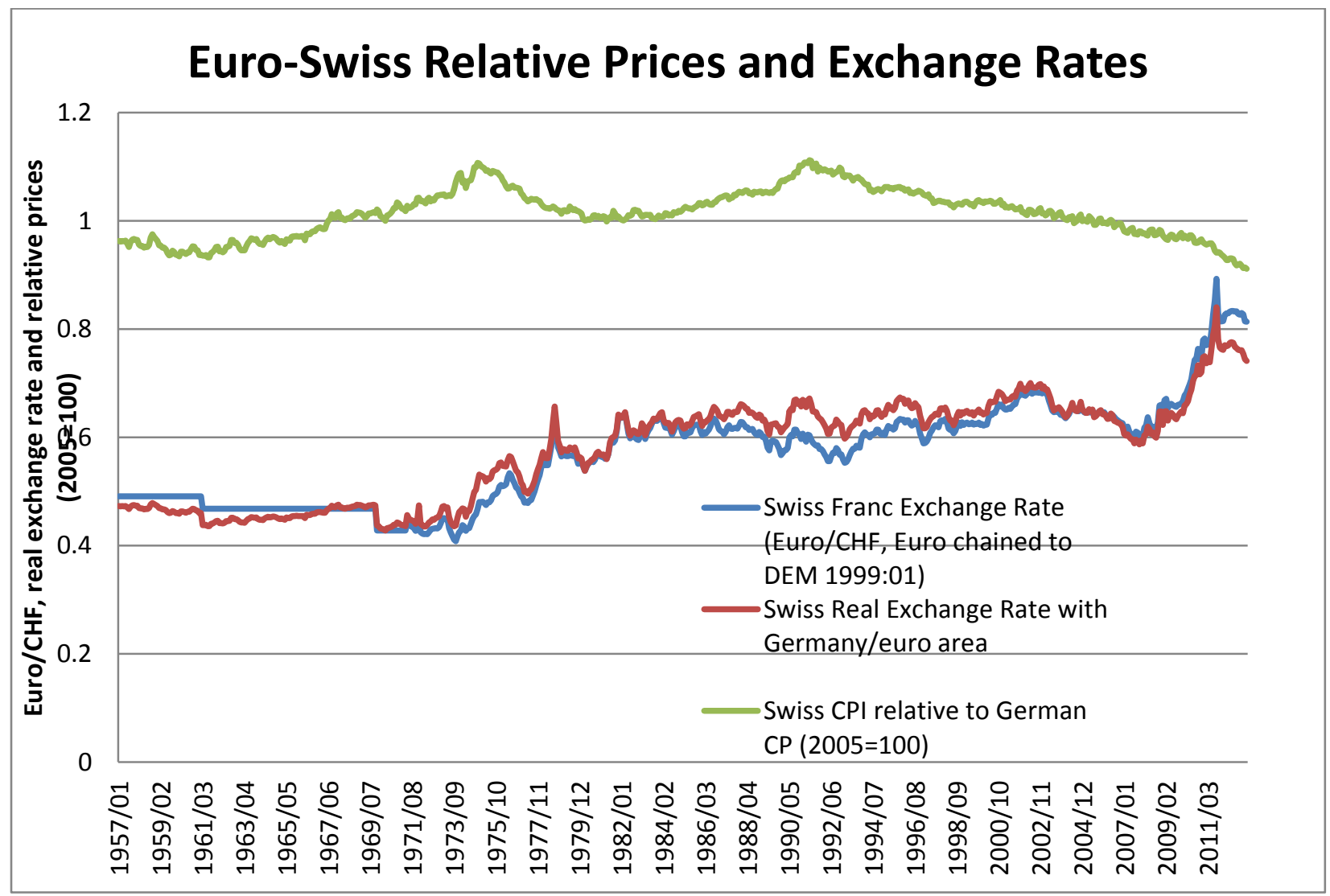


Recent inflation experience shows the same pattern of relatively low inflation as earlier, although it has persisted for longer. At the end of the Swiss appreciation (August 2011), the Swiss CPI had risen 0.2 percent over the previous year. German inflation was higher at 2.1 percent. At the end of the mid-1970s appreciation, Swiss inflation hit a low of 0.4 percent in August 1978, the month after the appreciation ended, well below German prices were 2.1 percent higher. Following the end of the mid-1970s appreciation, inflation turned in both Switzerland and Germany, with Swiss inflation increasing relatively more. In the year ending in December 1979, just over a year later, Swiss inflation surged to 5 percent, while German inflation rose somewhat less, to 5.1 percent. This is the expected pattern of a country's real appreciation. Inflation remains relatively low while the exchange rate appreciates and subsequently accelerates.

In the latest case, however, Swiss and German inflation have continued to remain low, with Swiss inflation hitting -1.0 percent in spring and early summer 2012 and then rising to -0.2 percent in February 2013. German inflation has declined, though somewhat less, so that for the year ending in February, German prices were up 1.5 percent, still 1.7 percent more than in Switzerland, though the difference peaked in March 2012, some six months after the end of the appreciation, when Swiss prices had fallen one percent and German prices were still up 2.1 percent from a year earlier. In the latest case, inflation remains low in both Switzerland and Germany, but a larger reversal is a major risk factor facing the Swiss National Bank.

\section{III.b Are Swiss Prices Tied to German Prices?}

In a closed economy, a country's price level is determined by its money supply (M) relative to its money demand because the price level is simply the inverse of the value of domestic money. One model of inflation $(\pi)$ that exploits this relationship is called the P-star model, where $\mathrm{P}^{*}$ is the equilibrium price level determined by the amount of money per unit of potential GDP $\left(y^{*}\right)$, adjusted for an equilibrium level of the velocity of money $\left(\mathrm{V}^{*}\right)$.

(1) $\mathrm{P}^{*}=M \mathrm{MV}^{*} / \mathrm{y}^{*}$

The level of domestic prices $(\mathrm{Pd})$ is expected to adjust to a policy determined equilibrium level that changes over time based upon the growth of a monetary aggregate, the economy's potential output and equilibrium velocity. See Baeriswyl et al. (2013) for a summary of the Swiss National Bank models used for the analysis of monetary policy and inflation, which include several variants of the P-star model. The primary difference between earlier P-star models and those at the SNB are that the equilibrium velocity of money takes into account movements in the long-term interest rate, since the demand for money varies inversely with the interest rate so that velocity is a positive function of the nominal long-term bond rate. 
An estimated version of the P-star model, using Swiss annual data from 1975 to 2012 for M2, potential GDP and velocity, is:

(2) $\pi_{\mathrm{t}}=-0.0002-0.0654\left(\ln \mathrm{P}_{\mathrm{t}-1}-\ln \mathrm{P}{ }_{\mathrm{t}-1}\right)+0.8742 \pi_{\mathrm{t}-1}$

(0.07) (-2.95)
Adjusted- $R^{2}=0.60$
D.W. $=2.31$

S.E. $=0.0113$

In this estimate, equilibrium velocity used to construct $\mathrm{P}^{*}$ is found using a standard HodrickPrescott filter for annual data, without adjustment for interest rates. When such an adjustment is made, the $\mathrm{P}^{*}$ model was not successful here. There are other differences as well including the omission of an oil price effect that is normally included. This model provides an adequate benchmark for testing foreign influences. Most noteworthy, the coefficient on the difference in the (logarithmic) level of prices and $\mathrm{P}^{*}$, the key component of the model, has the expected negative sign and is statistically significant. ${ }^{1}$

A small open economy with a floating exchange rate will determine its own equilibrium price level and inflation and the exchange rate will vary to allow prices domestically and abroad to be competitive with each other and to fully reflect only its own domestic money supply relative to its potential output. In this case, foreign price developments would have no effect on domestic inflation. But if the nominal exchange rate between two countries' currencies is fixed, the country fixing the exchange rate will import the equilibrium price level from its neighbor as it attempts to supply enough domestic money to keep its nominal exchange rate unchanged. Then prices in the small open economy are determined abroad.

Switzerland has had a flexible exchange rate since the breakdown of the Bretton Woods Agreement in August 1971. Before 1971, Switzerland had a fixed exchange rate with the U.S. dollar, and except for two German revaluations in March 1961 and November 1969, with Germany. The Swiss flexible exchange rate since then has been accompanied by the similar strong commitments to price stability in both countries, including during the euro regime since 1999. Were there to have been a strictly enforced fixed exchange rate between Germany (and later the Euro-area) and Switzerland, prices in Switzerland would have converged to those in Germany, so that the equilibrium Swiss price level, $\mathrm{P}^{\mathrm{f}}$ would tend to equal the German price level, Pg adjusted for the deviation of the nominal exchange rate $\mathrm{E}$ (euro/CHF) from its equilibrium level $\left(R^{2} R^{e}\right)$. The equilibrium real exchange rate is estimated using the HodrickPrescott filter for annual data.

\footnotetext{
${ }^{1}$ The implied lag for the full equilibrium impact of money growth on subsequent inflation in this model is relatively long, eight years. Reynard (2013) finds lags of three to five years for the United States, Euro-area and Switzerland.
} 
(3) $P^{f} *=\left(R E R^{e} / E\right) P g$

If the exchange rate regime is a managed float, not a purely floating or fixed rate system, matters are more complicated. Then, following Kool and Tatom (1994), the equilibrium Swiss price level can be viewed as a weighted average of equations 1 and $3, \mathrm{P}^{\mathrm{d} *}$, where the weight, w, reflects the weight associated with the degree to which the exchange rate is fixed.

(4) $P^{d *}=(1-w) P^{*}+w P^{f} *$

In this more general case, the model of the Swiss price level to be estimated is:

(5) $\pi_{\mathrm{t}}=\beta_{0}+\beta_{1}\left(\ln \mathrm{P}_{\mathrm{t}-1}-\ln \mathrm{P}_{\mathrm{t}-1}{ }^{\mathrm{d}} *\right)+\sum \beta_{\mathrm{j}} \pi_{\mathrm{t}-\mathrm{j}}+\varepsilon_{\mathrm{t}}$

The weighted-average equilibrium price level (4) replaces the domestic $\mathrm{P}^{*}$, which would also be the relevant measure if there is a pure floating exchange rate. To estimate this equation, the $P^{d *}$ term in equation 4 is substituted and the equality of the absolute size of the coefficients in the price gap term is relaxed resulting in:

(6) $\pi_{\mathrm{t}}=0.0718-0.0840 \ln \mathrm{P}_{\mathrm{t}-1}+0.0498 \ln \mathrm{P}_{\mathrm{t}-1}+0.0186 \ln \mathrm{P}^{\mathrm{f}}{ }_{\mathrm{t}-1}+0.7343 \pi_{\mathrm{t}-1}$
Adjusted-R2 $=0.60$
D.W. $=2.22$

S.E. $=0.0112$

According to this estimate the German based $\mathrm{P}^{*}$ measure $\left(\ln \mathrm{P}^{\mathrm{f} *}\right.$ ) is not statistically significant so its inclusion is not warranted and the weighted average formulation in equation 4 is not supported by the data. In contrast, the coefficients on the lagged domestic price and on the $\mathrm{P}^{*}$ term have the correct sign and the coefficient on the $\mathrm{P}^{*}$ term is statistically significant (5.3 percent). When the German based equilibrium price term is dropped from equation 6 , both the lagged domestic price and domestic P-star terms are significant and again have the right signs. More important, the constraint that the two terms have equal and opposite signs that is included in the domestic $P^{*}$ model in equation 1 cannot be rejected, $F(1,32)$ equals 2.13 (5\% critical value is 4.15$)$. Thus the $P^{*}$ model in equation 1 is not rejected by the more general managed exchange rate regime estimated in equation 6 . Instead, the evidence for a managed exchange rate system is rejected. The F-statistic for the two restrictions imposed on equation 6 to obtain equation 1 is $F(2,31)$ equlas 1.13 , which is far below the critical value (5 percent) of 3.32, so these restrictions cannot be rejected.

While the appropriate test of German influence on Swiss prices is to add lagged information on German prices to the $\mathrm{P}^{*}$ model, the high correlation of German and Swiss prices is suggestive of a contemporaneous link. A simpler test of whether German inflation affects Swiss inflation is simply to add German inflation $\left(\pi_{\mathrm{gt}}\right)$ to the domestic $\mathrm{P}^{*}$ model. 
(7) $\pi_{\mathrm{t}}=-0.0058-0.0524\left(\ln \mathrm{P}_{\mathrm{t}-1}-\ln \mathrm{P}_{\mathrm{t}-1}\right)+0.5174 \pi_{\mathrm{t}-1}+0.5754 \pi_{\mathrm{gt}}$

$(-1.88) \quad(-2.81)$

Adjusted- $\mathrm{R}^{2}=0.727$

S.E. $=0.0094$

German inflation does significantly affect Swiss inflation within the $\mathrm{P}^{*}$ model that includes the error correction process for domestic actual and equilibrium prices. A similar test for adding the other component of foreign equilibrium prices (RER/E) does not significantly improve the estimate in equation 7. The exchange rate influence from Germany is measured by the rate of change of the difference in the logarithm of (RER*/E). The t-statistic for adding this variable is only 0.60 , which rejects the addition of this term to equation 7. A test of a significant lagged term of either $\pi_{\mathrm{g}}$ or the growth rate of (RER*/E) rejects each. Also, the tests reported in Table 2 were confirmed by adding each country's inflation terms, current or lagged, to equation 7 and with the strange exception of Greece, none were significant. ${ }^{2}$ Since there is no reason to think that Greek monetary policy or inflation is significantly related to Swiss inflation or policy, the Greek result is simply an anomaly here.

It should be noted that if German prices influence the Swiss price level, then it is lagged German prices that should enter on the right-hand-side of equation 7, not current inflation. Without the current German inflation rate, the lagged logarithm of German price has a t-statistic of -1.46, which is not significant and has the wrong sign; lagged German inflation does worse $(t=0.92)$. Neither of these measures is significant if added to equation 7, i.e. when current German inflation is included. Thus a theoretical link between German prices and the equilibrium Swiss price level is not supported by the estimates here. We conclude that inflation in Germany is the only foreign factor potentially influencing Swiss inflation in the context of a Swiss P-star model, but this measure is not rooted the theory behind the $\mathrm{P}^{*}$ model. Indeed, appropriately testing such a German influence in this model rejects a German influence. The inflation result in equation 7 could arise because of an implicit exchange rate objective, or more likely because the implicit or explicit inflation objectives in each country have been very similar for many years.

\section{Cointegration}

Time series analysis also can reveal whether there is a long run-equilibrium relationship of Swiss prices or inflation and Germany's. In order to determine whether German prices and inflation influence their Swiss counterparts, three tests for unit roots were conducted: the

\footnotetext{
${ }^{2}$ When German inflation is excluded from equation 7, current inflation in five countries has a statistically significant positive effect on Swiss inflation. These are the U.S, Canada, Ireland, Sweden and Greece. When German inflation is also included, however, none of the other countries have a significant effect and the German inflation effect and other terms remain strongly significant.
} 
Augmented Dickey Fuller (ADF) test, the Generalized Least Squares (GLS) version of the ADF test (DF-GLS), and the Phillips-Perron test. Another test, the Kwiatkowski-Phillips-Shin-Stock (KPSS) LM test statistic for stationarity is also reported. These test statistics are reported in Table 3. Critical values for 5 percent significance levels are indicated, though many of the hypotheses are rejected at a one percent level.

The table shows that the CPI in Switzerland and the first difference of its log level are not stationary. The log level of the CPI is integrated of order two I(2), meaning that it must be differenced twice to achieve stationarity, according to the evidence in the first row of the table. Swiss inflation is also not stationary according to the unit root tests in the fourth row, as a unit root cannot be rejected, except for the DF-GLS test using the Elliott-Rothenberg-Stock test statistic. More importantly, the KPSS LM statistic rejects stationarity. The first-difference in Swiss inflation is stationary, however, according to the unit root and stationarity tests reported in the fifth row of the table.

Table 3

Unit Root Tests for Swiss and German Prices, Inflation and the Exchange Rate

\begin{tabular}{|l|l|l|l|l|}
\hline Variable & $\begin{array}{l}\text { ADF } \\
(\text { critical value: }- \\
2.92)^{* *}\end{array}$ & $\begin{array}{l}\text { DF-GLS } \\
(\text { critical value:- } \\
2.47)^{* *}\end{array}$ & $\begin{array}{l}\text { Phillips-Perron } \\
\text { (critical value: } \\
2.92)^{* *}\end{array}$ & $\begin{array}{l}\text { KPSS } \\
\text { (Stationarity) } \\
\text { (critical value: } \\
0.46)^{* *}\end{array}$ \\
\hline $\mathrm{LN}($ Swiss CPI) & -0.41 & -0.41 & -2.18 & $0.86^{*}$ \\
\hline $\mathrm{LN}($ German CPI) & -0.41 & 0.01 & -1.56 & $0.89^{*}$ \\
\hline$(\mathrm{LPCH}-\mathrm{LPG})$ & -1.30 & -1.27 & -1.12 & 0.24 \\
\hline $\begin{array}{l}\text { Swiss } \\
\text { inflation }\left(\pi_{\mathrm{CH}}\right)\end{array}$ & -2.42 & $-2.47^{*}$ & -2.62 & $0.54^{*}$ \\
\hline $\mathrm{D}\left(\pi_{\mathrm{CH}}\right)$ & $-6.89^{*}$ & $-4.66^{*}$ & $-7.26^{*}$ & 0.24 \\
\hline German inflation & $-3.26^{*}$ & $-3.16^{*}$ & -2.56 & 0.33 \\
\hline $\mathrm{DIn}(\mathrm{EX})$ & $-9.08^{*}$ & $-8.23^{*}$ & $-9.20^{*}$ & 0.20 \\
\hline$\left(\pi_{\mathrm{CH}}-\pi_{\mathrm{G}}\right)$ & $-8.25^{*}$ & $-6.03^{*}$ & $-11.14^{*}$ & 0.40 \\
\hline $\mathrm{D}(\operatorname{Irer})$ & $-9.93^{*}$ & $-9.12^{*}$ & $-9.85^{*}$ & 0.10 \\
\hline
\end{tabular}

$* *$ Critical values for 5 percent significance level.

*Statistically significant rejection at a 5 percent level or less.

In Germany, however, inflation is an I(0) process or stationary, according to two of the three unit root tests and to the inability to reject stationarity in the last column of the sixth row. In this case, Swiss prices cannot be cointegrated with German prices. It is possible that these are weak tests, however. It is also possible that the Swiss inflation result is peculiar to the particular sample used. The latter is suggested by the fact that other tests in the table indicate that Swiss and German inflation are tied together, in particular that the difference in the inflation rates is stationary (row 8), or Swiss and German prices are in fact cointegrated, which would require 
that Swiss and German prices are integrated of the same order. The growth rate of the real exchange rate for the two countries (last row) also is stationary, according to all three unit root tests and the stationarity test. These results also suggest that the Swiss domestic price inflation rate equals the inflation rate for Swiss prices of German goods and services.

Also, the rate of growth ( $d \mathrm{ln}$ ) of the nominal Euro-Swiss Franc exchange rate is stationary in Table 2, according to the three tests that reject a unit root and the inability to reject stationarity, as is the difference in Swiss and German inflation rates. Thus, the two inflation measures are co-integrated or tied together so that Swiss inflation is tied to German inflation in a fixed, long-run equilibrium relationship. The growth of the real exchange rate (RER) exhibits the same absence of a unit root and stationarity. This indicates that inflation rates and the growth rate of the nominal exchange rate are locked in a statistically significant long-run relationship.

A simple test to examine the sensitivity of the Swiss CPI result in Table 3 is to redo the tests there for other sample periods. There is a trade off in losing observations in looking at shorter periods of time. A first step was to simply shorten the sample period one year at a time to see whether the result is due to the unusual experience since the Swiss recession and U.S. financial crisis. The top line in Table 4 shows the results for the time period 1957-2008. In this case, Swiss inflation is found to be stationary, or a unit root is rejected, except for the Phillps-Perron test, which often fails to reject a unit root in the tests and periods used in Tables 2 and 3. So it does appear that the Table 2 result that the Swiss CPI is I(2) is peculiar to the inclusion of the most recent data. To be fair, other periods that started later were examined. The other periods used in the table were 40 years long starting in 1957 and moving forward in five year increments. Once again Swiss CPI is I(1) in every sample except those including the most recent observations. For every period beginning from 1957 through 1975 and running through 2008, the Augmented Dickey-Fuller test rejects a unit root, except for 1970-71 and 1973, where the significance levels are only slightly above 5 percent. Thus the cointegration results for inflation and for the real exchange rate change in Table 3 can be taken seriously.

We conclude that Swiss inflation is statistically significantly tied to German inflation and in a way not found for 17 other countries, both within and outside the Euro-area. It was not found to be causal in a Granger sense, according to the tests in the previous section, however. The implications are that the real exchange rate appreciation of the Swiss franc is not likely the source of deflation in Switzerland, but a potential rise in Euro-area, especially German, inflation does pose a risk to inflation in Switzerland. 
Table 4

Alternative Sample Periods Indicate Swiss Inflation is Stationary

\begin{tabular}{|l|l|l|l|c|}
\hline & $\begin{array}{l}\text { ADF } \\
\text { (critical value: } \\
2.97)^{* *}\end{array}$ & $\begin{array}{l}\text { DF-GLS } \\
\text { (critical value:- } \\
1.95)^{* *}\end{array}$ & $\begin{array}{l}\text { Phillips-Perron } \\
\text { (critical value: }- \\
2.96)^{* *}\end{array}$ & $\begin{array}{l}\text { KPSS } \\
\text { (Stationarity) } \\
\text { (critical value: } \\
0.46)^{* *}\end{array}$ \\
\hline $1957-2008$ & $-3.50^{*}$ & $-3.29^{*}$ & -2.68 & 0.39 \\
\hline $1957-1997$ & $-3.64^{*}$ & $-3.19^{*}$ & -2.51 & 0.15 \\
\hline $1962-2002$ & $-3.19^{*}$ & $-2.90^{*}$ & -2.66 & 0.45 \\
\hline $1967-2007$ & $-2.95^{*}$ & $-3.00^{*}$ & -2.47 & $0.56^{*}$ \\
\hline $1972-2012$ & 2.15 & -1.58 & -1.75 & $0.72^{*}$ \\
\hline
\end{tabular}

IV. Does Globalization Affect Domestic Inflation?

The literature on foreign effects on domestic inflation made a major turn in 2005 with the work of Borio and Filardo (2005) who argued that globalization had led inflation to become a global process, with domestic GDP gaps no longer mattering for domestic inflation and the global GDP gap mattering more. This work sparked considerable debate subsequently. In this and related studies the question was not whether inflation in industrial countries was driven by foreign inflation or inflation in neighboring countries or among large trading partners with similar monetary policies, it was whether global factors, especially due to the integration of emerging markets, had changed the domestic inflation process to a global one. Kohn (2006) notes that globalization has had no effect on modeling of inflation as late as fall 2005. Kohn carefully reviews several of the channels of potential influence of globalization on inflation in the context of a standard model of the Phillips Curve. He suggests that the domestic gap coefficient has been declining in the U.S. and he points to a simulation of a Fed model run to 1985 that would over predict inflation in a 2001-06 simulation by about 0.1 to 0.2 percent per year for core PCE inflation and 0.5 to 1.0 percent per year for core CPI inflation. But he attributes these errors to dollar appreciation and technological change over the period instead of globalization. Kohn argues that an important effect might arise from the rise in global manufacturing capacity and that a decline of the domestic GDP gap coefficient of about one-third in the Fed's model is consistent with that. But he notes that this decline could more readily have arisen because of lower inflation and increased credibility of monetary policy.

There have been many papers responding to the challenge of the globalization literature. Razin and Loungani (2005) argue that increased openness flattened the Phillips curve so that a given rise in output required a smaller rise in inflation than earlier. Thus, monetary authorities should pay less attention to the domestic GDP gap and put more weight in holding down inflation, in their view. They conjecture that the correlation of the domestic output gap and consumption expenditures should decline. Borio and Filardo (2005) find supporting evidence for a decline in 
the coefficient on the domestic output gap across many industrial countries, but argue that it is now the global gap that should matter for domestic inflation. The IMF (2006) produces one of the most comprehensive studies and favorable of the various channels of influence of globalization. In the end, however, most analysts are not convinced of the influence of globalization and more importantly suggest that policy makers should stick to a focus on domestic inflation. Even the IMF questions the persistence of effects from globalization, especially during periods of strong global cyclical expansion.

One of the best early critiques of the globalization hypothesis is Ball (2006). He argues against what can be called an "adding up approach" to inflation based on movements of particular prices. He notes that globalization could lead to relative price changes for many goods, but that inflation does not depend on movements in relative prices. Of course a large relative price movement of an economic resource or input in the production process reflects increased scarcity of the resource that would lower production and raise the price level, but such changes are not frequent. Ball shares with Gnan and Valderama (2012) the conclusion that the global gap in Borio and Filardo does not stand scrutiny, or in the latters' view, is never statistically significant beyond the highly correlated effects of the domestic gap in every case examined. Gnan and Valderama argue that improvements in monetary policy are more likely to account for the decline in inflation since the 1980s because of a more limited potential for "inflation surprises." They do suggest that the rise of emerging markets and their financing by global private investors played a role as the perception that inflation signaled poor economic policy and political and economic stability became more important.

Gali (2010) focuses on a macroeconomic approach in which there are two channels of influence of globalization on domestic prices and inflation. The first is that globalization can boost world real output raising the real exchange rate of more developed countries and lowering domestic prices. The second channel is the growth in world demand which can raise the domestic price level in more developed countries. Gali shows that it is possible for these two forces to exactly offset or for one or the other to dominate. Ihrig, Kamin, Lindner and Marquez (IKLM, 2007) provide the most extensive empirical investigation of the globalization hypothesis that there is an increasing role of international factors and a declining role of domestic factors in the inflation process in 11 industrial countries for the quarters from 1977 through 2005 and find it wanting.

Generally, IKLM find that the foreign gap is not statistically significant and often has the wrong sign, there is no evidence of a declining sensitivity of inflation to the domestic gap and no increase in the sensitivity of domestic inflation over time to import prices for most countries. They do argue that globalization may be stabilizing because it may reduce the volatility of real GDP by more than it reduces the volatility of domestic demand so that real net exports serve as an increasing buffer for output from fluctuations in demand. 
IKLM include Switzerland in their study. As they and others have observed for other countries, the effect of the Swiss domestic GDP gap on inflation has shown a declining trend and is generally insignificant in a 1985-2005 period, but they find that a foreign output gap measure has also had a declining coefficient and is not significant in either of two sample periods: 197705 and 1985 -2005. They find no evidence that a very small import price effect on Swiss core inflation has been rising and it is never statistically significant at a 90 percent confidence level. Moreover, it often has the wrong sign, especially in 2003-04. However, they do find that the trend of Swiss net exports as a share of GDP has risen since 1990.

IKLM provide some evidence that Swiss real GDP and domestic demand growth are positively correlated and the correlation rose from 1989 to 1997, but it declined sharply from the 10-year period ending in 1997 until the 10-year period ending in 2006. For the last several years of their sample of 10 -year correlations, the correlation has been about 0.35 to 0.40 , which is relatively small compared with the correlation in most other countries.

The IKLM hypothesis that globalization could reduce the volatility of GDP by more than that of domestic demand is not supported by Swiss evidence. Just the reverse is observed in Chart 2. Real GDP growth volatility did decline, but the volatility of domestic demand growth declined relatively more, especially after the 10-year period ending in 1984 and the 10-year period ending in 1998. Globalization apparently is not stabilizing Swiss production growth as much as the declining volatility of domestic demand.

\section{Chart 3}

Globalization has not stabilized relative domestic demand growth in Switzerland

\section{The volatility of Swiss domestic demand growth has declined more than that of real GDP}

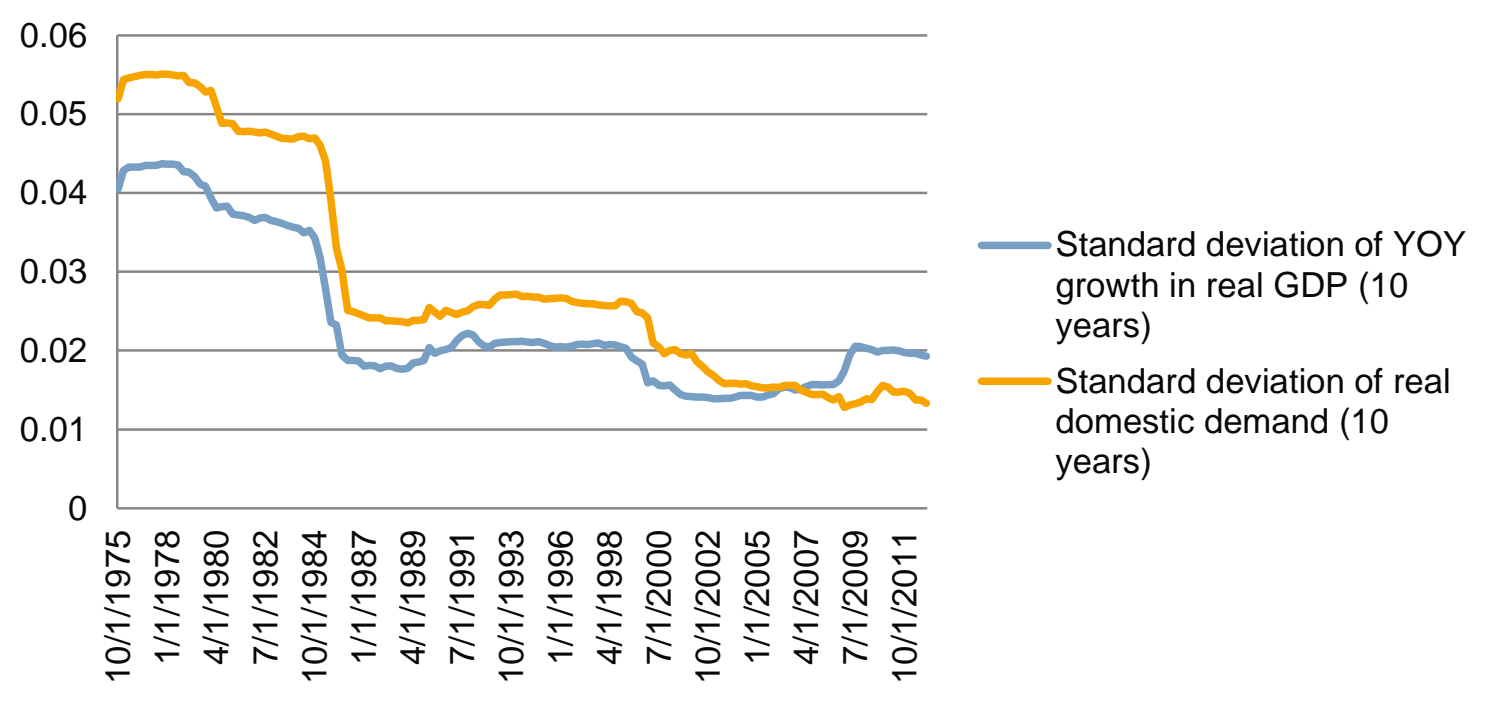


The literature is fairly strong in achieving consensus that globalization does not lower inflation in industrial countries. This is consistent with the results above for causality of inflation from Euro-area and major industrial countries that inflation in Switzerland is not caused by inflation abroad. Ironically, there is some evidence above that inflation in five to seven Euro-area countries is significantly affected by Swiss inflation developments, however.

\section{Conclusion}

Historically, Swiss inflation has been relatively low, largely because of a strong policy emphasis on price stability, reinforced perhaps by the importance of Switzerland as a financial center attracting foreign capital, especially during the Great Inflation and during past crises. This paper reviews the literature and experience with inflation since the Great Moderation and the Swiss experience in the recent financial crisis and subsequently, focusing especially on the recurring concerns for foreign influences from other industrial countries, perhaps especially Euro-area countries, Germany or emerging markets. We find no evidence that inflation is globally determined. There is evidence presented of a cointegrating relationship of Swiss and German inflation, but this and the high correlation of Swiss and German inflation are more likely due to common inflation objectives. Swiss inflation is largely made at home. The risk from abroad is not so much that past actions to limit Swiss appreciation will lead to a surge of inflation, but rather that Euro-area monetary policy could lead to an acceleration there and that Swiss inflation, as in the late 1970s, might surge along with it. 


\section{References}

Baeriswyl, Romain, Nicolas Cuche-Curti, Sylvia Kaufmann, Michel Peytrignet, and Samuel Reynard (2013). Monetary Analysis and Policy Implications in Switzerland, internal study, Swiss National Bank.

Ball, Laurence M. (2006). "Has Globalization Changed Inflation?" National Bureau of Economic Research Working Paper No. 12687 (November).

Baltensperger, Ernst (2007). “The National Bank's Monetary Policy: Evolution of Policy framework and Policy Performance," in Die Schweizerische Nationalbank, Die Schweizerische Nationalbank, 1907-2007. Zürich: Neue Zürcher Zeitung.

Belongia, Michael T, and Peter N. Ireland (2012). “Quantitative Easing: Interest Rates and Money in the Measurement of Money," Boston College Department of Economics Working Paper 801.

Bernanke, Ben S. and Alan S. Blinder (1988). “Credit, Money, and Aggregate Demand," American Economic Review 78 (May), 435-39.

, and (1992). "The Federal Funds Rate and the Channels of Monetary

Transmission," American Economic Review 92 (September), 901 - 21.

Borio, Claudio and Andrew Filardo (2007). "Globalization and Inflation: New Evidence on the Global Determinants of Domestic Inflation," Bank for International Settlements Working Paper No. 227. $r$

Ciccarelli, M. and B. Mojon, B. (2010). "Global Inflation," Review of Economics and Statistics 92(3), 524-535.

Estrella, Arturo and Frederic S. Mishkin (1997). "Is There a Role for Monetary Aggregates in the Conduct of Monetary Policy?" Journal of Monetary Economics 40, 279-304.

Gali, Jordi (2010). Inflation Pressures and Monetary Policy in a Global Economy," International Journal of Central Banking, 6(No. 1, March), pp. 93-102.

Gattini, L. Pill, H, Schuhknecht L. (2012). A Global Perspective on Inflation and Propagation Channels, European Central Bank Working Paper 1462. z 
Gnan, Ernest and Maria Teresa Valderrama (2006). "Globalization and Monetary Policy," Austrian National Bank, Monetary Policy and the Economy Q4/06.

Hall, Stephen G., P.A.V.B. Swamy and George Tavlas (2012). “Milton Friedman, Demand for Money and the ECB's Monetary Policy Strategy," Federal Reserve Bank of St. Louis Review 94 (No.3, May/June), 153-86.

Ihrig, Jane, Steven Kamin, Deborah Lindner, and Jaime Marquez (2007). "Some Simple Tests of the Globalization and Inflation Hypothesis, " Board of Governors of the Federal Reserve System, International Finance Discussion Papers No. 891 (April).

IMF (2006). “How Has Globalization Affected Inflation," Chapter III, World Economic Outlook, pp. 97-134.

Kohn Donald L. (2006). "The Effects of Globalization on Inflation and the Implications for Monetary Policy," in Federal Reserve Bank of Boston, Appropriate Adjustment Considerations and Policies, pp. 341-349.

Kool, Clemens J.M., and John A. Tatom (1994). "The P-Star Model in Five Small Economies, Federal Reserve Bank of St. Louis Review 76 (3)May/June, pp. 11-30.

Leeper, Eric M. and Jennifer E. Roush (2003). "Putting 'M' Back in Monetary Policy," Journal of Money, Credit and Banking 35,December, 1217-1256.

McCallum, Bennett T. and Edward Nelson (2011). Money and Inflation: Some Critical Issues," in Benjamin M. Friedman and Edward Nelson (Eds.), Handbook of Monetary Economics, Volume 3A, Amsterdam: Elsevier/North Holland, 97-153.

Meltzer, Allan H. (2005). "Origins of the Great Inflation," Federal Reserve Bank of St. Louis Review 87, (March/April, part 2), pp. 145-175.

Mishkin, Frederic S. (2007). “Inflation Targeting: True Progress or Repackaging of an Old Idea?" in Die Schweizerische Nationalbank, Die Schweizerische Nationalbank, 1907-2007. Zürich: Neue Zürcher Zeitung.

Neumann, Manfred J.M. (2007). „Monetary Policy Under Flexible Exchange Rates: an Assessment, " in Die Schweizerische Nationalbank, Die Schweizscherische Nationalbank, 19072007. Zürich: Neue Zürcher Zeitung.

Morley, James, Jeremy Piger and Robert Rasche (2012). "Inflation in the G-7: Mind the Gaps," September, working paper presented at Federal Reserve Bank of St. Louis. 
Neely, Christopher J. and David E. Rapach (2011). "International Co-Movements in Inflation Rates and Country Characteristics," Journal of International Money and Finance 30 (2011), pp. 1471-1490.

Piger, Jeremy M. and Robert H. Rasche (2008). “Inflation: Do Expectations Trump the Gap?” International Journal of Central Banking 4 (4), December, pp. 85-116.

Razin, Assaf and Prakish Loungani (2005). "Globalization and Inflation-Output Tradeoffs," Natioinal Bureau of Economic Research Working Paper No. 11641 (September).

Reynard, Samuel (2007). "Maintaining Low Inflation: Money, Interest Rates, and Policy Stance," Journal of Monetary Economics 54, pp. 1441-71.

Sanchez-Fung, Jose R. (2012). "Examining the Role of Monetary Aggregates in China," Bank of Finland Institute for Economies in Transition, BOFIT Discussion Paper 18.

Tatom, John A. (1996). "Swiss Exchange Rate Appreciation and Domestic Economic Activity," Swiss Journal of Economics and Statistics 132 (3), pp. 473-94.

Woodford, Michael (2008). "How Important is Money in the Conduct of Monetary Policy?" Journal of Money Credit and Banking 40, 1561-98.

(2009). "Globalization and Monetary Control'” in Jordi Gali and Mark Gertler (Eds.), International Dimensions of Monetary Policy, Chicago: University of Chicago Press, 13-17. 